\title{
Infectious mononucleosis complicated by acute haemolytic anaemia with a positive Donath- Landsteiner reaction
}

\author{
M. M. WISHART AND M. G. DAVEY \\ From the Department of Pathology, Fremantle Hospital, Fremantle, Western Australia
}

SYNOPSIS A patient with infectious mononucleosis complicated by acute haemolytic anaemia is described. The patient had, in addition to non-specific cold agglutinins in the serum, a positive Donath-Landsteiner reaction in the absence of syphilis. The association of a positive DonathLandsteiner reaction with haemolytic anaemia in infectious mononucleosis has been described only once before.

Acute haemolytic anaemia is an uncommon complication of infectious mononucleosis. In a recent survey of the literature on this subject only 53 cases were found (Worlledge and Dacie, 1969). Hoagland (1967) stated that approximately $3 \%$ of the patients in his series of 500 cases had haemolytic anaemia.

In addition to the heterophil antibodies reactive with sheep red cells, which are a major criterion for the diagnosis of infectious mononucleosis, patients with this condition have often been found to have other hetero- and autoantibodies in the course of the illness. These include reagins, which give rise to false positive Wassermann reactions (Zarafonetis and Kent, 1954; Carter 1966), rheumatoid factor, antinuclear factor, an antibody similar to antithyroglobulin, and possibly leucoagglutinins (Carter, 1966). Autoantibodies to red cells are found not infrequently and may be associated with autoimmune haemolytic anaemia. Those most commonly described are cold agglutinins, either non-specific (Ellis, Wollenman, and Stetson, 1948; Green and Goldenberg, 1960; Fekete and Kerpelman, 1965) or with anti-i specificity (Rosenfield, Schmidt, Calvo, and McGinniss, 1965; Jenkins, Koster, Marsh, and Carter, 1965; Calvo, Stein, Kochwa, and Rosenfield, 1965; Troxel, Innella, and Cohen, 1966). A number of patients have been investigated fruitlessly for cold haemolysins of the Donath-Landsteiner type (Green and Goldenberg, 1960; Kostinas and Cantow, 1966); only one case of infectious mononucleosis with haemolytic anaemia and a positive DonathLandsteiner reaction has actually been recorded (Ellis et al, 1948). This paper presents a second case Received for publication 28 February 1973. of this association occurring in the absence of syphilitic infection.

\section{Case Report}

The patient, a white male aged 17 years, was admitted to Fremantle Hospital on 20 July 1971, with a threeday history of dull, constant epigastric pain, anorexia, headache, weakness, tiredness, and passing dark urine. He was an English migrant and had arrived by air in Australia eight days earlier. Before leaving England he had been well and had no known contact with patients suffering from hepatitis or infectious mononucleosis, nor any exposure to drugs or toxic chemicals.

He was mildly jaundiced and afebrile. There was mild, generalized, painless lymphadenopathy, particularly of the cervical, posterior cervical, and epitrochlear glands. The spleen was palpable $3 \mathrm{~cm}$ below the left costal margin and was tender. Theliver was palpable $2 \mathrm{~cm}$ below the right costal margin and was also slightly tender. No other abnormalities were noted on examination.

Results of the most relevant investigations performed on admission and subsequently are set out in the table. The Paul-Bunnell test was performed by the State Health Laboratories, Perth, using the technique of Davidsohn (1937) as outlined by Wintrobe (1946). The Donath-Landsteiner test was performed using both the direct and indirect technique as set out by Boorman and Dodd (1970). Immunoglobulin levels were determined by radial immunodiffusion on Tripartigen plates (Behringwerke).

In addition to these, on presentation a screening 


\begin{tabular}{|c|c|c|c|c|}
\hline \multirow[t]{2}{*}{ Investigation } & \multicolumn{4}{|l|}{ Date } \\
\hline & 21 July 1971 & 26-29 July 1971 & 6 August 1971 & 1 December 1971 \\
\hline Haemoglobin $(\mathrm{g} / 100 \mathrm{ml})$ & $9 \cdot 0$ & $11 \cdot 1$ & $13 \cdot 0$ & $15 \cdot 8$ \\
\hline Haematocrit $(\%)$ & 30 & 33 & 39 & 49 \\
\hline Reticulocytes $(\%)$ & $3 \cdot 3$ & $9 \cdot 8$ & 3.0 & $1 \cdot 7$ \\
\hline White cells per $\mathrm{mm}^{3}$ & 11200 & 6800 & 4100 & 6000 \\
\hline Lymphocytes per $\mathrm{mm}^{3}$ & $9400^{1}$ & $4600^{1}(64 \%$ atypical $)$ & $2500^{1}$ & - \\
\hline ESR (Westergren) (mm/hr) & 60 & 21 & - & 2 \\
\hline Direct Coombs test & Positive & - & Negative & Negative \\
\hline Cold agglutinins & 1 in 128 & - & 1 in 128 & 1 in 4 \\
\hline Donath-Landsteiner reaction & Positive & Positive & Negative & Negative \\
\hline IM spot test (Denco) & Positive & - & - & - \\
\hline Paul Bunnell reaction & 1 in $112^{2}$ & 1 in 56 & - & Negative \\
\hline Wassermann reaction & Positive & Positive & - & Negative \\
\hline $\begin{array}{l}\text { Serum bilirubin }(\mathrm{mg} 100 \mathrm{ml} \text { ) } \\
\text { (direct reacting) }\end{array}$ & $\begin{array}{l}2 \cdot 3 \\
(0 \cdot 7)\end{array}$ & 0.8 & - & 0.8 \\
\hline Serum alkaline phosphatase & 11 & 14 & - & $9 \cdot 5$ \\
\hline SGOT (normal range $0-35 \mathrm{IU} / \mathrm{ml}$ ) & 83 & 100 & - & 34 \\
\hline SGPT (normal range 0-35 $\mathrm{Karmen} \mathrm{U} / \mathrm{ml}$ ) & 82 & 138 & - & 10 \\
\hline $\begin{array}{l}\text { Haptogiooins (mg/100 mi naemogiooin-oinding } \\
\text { capacity) }\end{array}$ & 0 & 40 & - & 75 \\
\hline \multicolumn{5}{|l|}{ Immunoglobulins $(\mathrm{mg} / 100 \mathrm{ml})$} \\
\hline IgG (Normal range $800-1600$ ) & & 1160 & 1330 & 1250 \\
\hline IgA (Normal range 90-500) & & 315 & 315 & 100 \\
\hline IgM (Normal range $80-300$ ) & & 140 & 243 & 140 \\
\hline
\end{tabular}

Table I Results of principal investigations

'Atypical lymphocytes of the type seen in infectious mononucleosis present.

${ }^{2}$ The Paul Bunnell reaction initially was also positive at 1 in 112 after absorption with guinea pig red cells, and negative at 1 in 14 after absorption with ox red cells.

test for red cell glucose-6-phosphate dehydrogenase deficiency, Ham's acid serum test, Hartmann's sugar-water test, and examination of a blood film for Heinz bodies were all negative. His serum contained methaemalbumin and his urine contained methaemoglobin and an increased amount of urobilinogen, but no bilirubin or haemosiderin. The VDRL flocculation and Reiter protein complement-fixation tests on the patient's serum were, and remained, negative. Examinations for LE cells were negative.

Neither the cold agglutinin nor the cold haemolysin showed any identifiable serological specificity. This was confirmed by the West Australian Blood Group Reference Laboratory at the Red Cross Blood Transfusion Service, Perth. Some reactivity was observed with papainized red cells even at $37^{\circ} \mathrm{C}$.

The day following admission the patient developed an urticarial rash which persisted for two days and was treated with calamine lotion. His clinical condition gradually improved. After two further days he had no more epigastric pain; he was feeling weak, but otherwise well, and he was discharged home one week later.

When reviewed a week later, he felt quite well apart from some left subcostal discomfort at night, and he was not icteric. There were a few small lymph nodes palpable in the axillae and inguinal regions. The liver edge was just palpable and tender and the spleen was felt $2 \mathrm{~cm}$ below the left costal margin and was still tender.
About four months later he remained well with no jaundice or recurrence of symptoms. His spleen and liver were not palpable and there was no significant lymphadenopathy.

\section{Discussion}

Dameshek (1943) first described a possible case of acute haemolysis complicating infectious mononucleosis. Since then at least 53 such cases have been reported (Worlledge and Dacie, 1969). The haemolysis is typically transient (Dacie, 1962) and in most instances develops one to two weeks after the onset of the illness, although in some cases haemolytic anaemia and infectious mononucleosis develop simultaneously (Dacie, 1962).

The patient described had a transient haemolytic episode lasting only a few days and apparently simultaneously with the onset of infectious mononucleosis. That the patient was actually suffering from infectious mononucleosis was confirmed by the typical morphological changes in his blood picture and by the presence of heterophil antibodies reactive with sheep red cells (the Paul-Bunnell test). A titre of 1 in 112, as in this case, is considered a 'borderline titre' (Davidsohn, 1937) but other causes of an elevated titre are ruled out in this case by the result of the differential absorption test (Davidsohn, 1937; Davidsohn, Stern, and Kashiwagi, 1951), and would be considered diagnostic by these authors. 
The most interesting aspect of this case is the presence of a cold haemolysin in the serum in the absence of syphilis. Ellis et al (1948) described a patient with a history suggestive of virus pneumonia but with a blood picture suggestive of infectious mononucleosis and a heterophil antibody titre of $1: 1024$. Differential absorption titres were not performed. Cold agglutinins against human group $O$ cells were present to a titre of 1 in 256 and agglutination also took place at room temperature, not dispersing completely at $37^{\circ} \mathrm{C}$. The DonathLandsteiner reaction was positive for at least seven weeks, although there was no serological evidence of syphilis. We were unable to find any other evidence in the literature of this finding in a case of haemolytic anaemia complicating infectious mononucleosis. Kostinas and Cantow (1966) studied Donath-Landsteiner reactions in 41 cases of infectious mononucleosis and all were negative. Green and Goldenberg (1960) reported a case of acute haemolytic anaemia complicating infectious mononucleosis with a positive direct Coombs test and cold agglutinins to a titre of $1: 256$. The DonathLandsteiner reaction was negative.

The patient described in this report had a positive Donath-Landsteiner reaction both when the patient's fresh serum was tested with his own red cells and with normal red cells, both with and without an added source of complement. It remained positive for at least eight days. This antibody is usually found only in association with syphilis (Becker, 1948; Dacie, 1962), but it has been described infrequently in the absence of syphilis (Sweetnam, Murphy, and Woodcock, 1952; Dacie, 1954).

This patient had a positive Wassermann reaction at the acute stage of his illness which reverted to negative without treatment. The other serological tests for syphilis performed (VDRL flocculation test and Reiter protein complement-fixation test) were negative at all times. There was no clinical evidence of syphilis at any time. Transient false positive Wassermann reactions have been described in infectious mononucleosis (Carter, 1966), and it would appear that this was the case in this patient. Of particular interest in this regard is the patient reported as case report no. 18 by Dacie (1954). The patient was a little girl who developed paroxysmal cold haemoglobinuria following an attack of measles. She had a positive DonathLandsteiner reaction, and in the acute stage of her illness a doubtful positive Wassermann reaction. Other serology for syphilis was negative, and there was no clinical evidence of congenital syphilis.

The clinical course and investigation of this patient led us to conclude that he suffered from infectious mononucleosis, complicated by autoimmune haemo- lytic anaemia associated with cold autoagglutinins and a cold haemolysin of the Donath-Landsteiner type, and by mild hepatitis. While his Wassermann reaction was positive during the acute illness, there was no historical, clinical, or other serological evidence of syphilis.

$\mathrm{He}$ did not show the typical syndrome of paroxysmal cold haemoglobinuria; in the mild winter climate of Perth this is not surprising.

We wish to thank Dr J. D. Woods for allowing us to study the patient, and Dr G. A. Leyland, medical superintendent, Fremantle Hospital, for permission to publish this report.

\section{References}

Becker, R. M. (1948). Paroxysmal cold hemoglobinurias. Arch. intern. Med., 81, 630-648.

Boorman, K. E., and Dodd, B. E. (1970). An Introduction to Blood Group Serology, 4th ed., pp. 298-299. Churchill, London.

Calvo, R., Stein, W., Kochwa, S., and Rosenfield, R. E. (1965). Acute hemolytic anemia due to anti-i; frequent cold agglutinins in infectious mononucleosis. J. clin. Invest., 44, 1033.

Carter, R. L. (1966). Antibody formation in infectious mononucleosis. 2. Other 195 antibodies and false-positive serology. Brit. J. Haemat., 12, 268-275.

Dacie, J. V. (1954). The Haemolytic Anaemias, pp. 287-290. Churchill, London.

Dacie, J. V. (1962). The Haemolytic Anaemias. Pt II. The AutoImmune Haemolytic Anaemias, 2nd ed., pp. 534-535, 569-573. Churchill, Londun.

Dameshek, W. (1943). Cold hemagglutinins in acute hemolytic reactions in association with sulfonamide medication and infection. J. Amer. med. Ass., 123, 77-80.

Davidsohn, I. (1937). Serological diagnosis of infectious mononucleosis. J. Amer. med. Ass., 108, 289-295.

Davidsohn, I., Stern, K., and Kashiwagi, C. (1951). The differential test for infectious mononucleosis. Amer. J. clin. Path., 21. 1101-1113.

Ellis, L. B., Wollenman, O. J., and Stetson, R. P. (1948). Autohemagglutinins and hemolysins with hemoglobinuria and acute hemolytic anemia in an illness resembling infectious mono-" nucleosis. Blood, 3, 419-430.

Fekete, A. M., and Kerpelman, E. J. (1965). Acute hemolytic anemia complicating infectious mononucleosis. J. Amer. med. Ass., 194, 1326-1327.

Green, N., and Goldenberg, H. (1960). Acute hemolytic anemia and hemoglobinuria complicating infectious mononucleosis. Arch. intern. Med., 105, 108-111.

Hoagland, R. J. (1967). Infectious Mononucleosis, p. 64. Grune and Stratton, New York and London.

Jenkins, W. J., Koster, H. G., Marsh, W. L., and Carter, R. L. (1965). Infectious mononucleosis: an unsuspected source of anti-i. Brit. J. Haemat., 11, 480-483.

Kostinas, J. E., and Cantow, E. F. (1966). Studies on infectious mononucleosis I antibodies. Amer. J. med. Sci., 252, 721-725.

Rosenfield, R. E., Schmidt, P. J., Calvo, R. C., and McGinnis, M. H. (1965). Anti-i, a frequent cold agglutinin in infectious mononucleosis. Vox Sang. (Basel), 10, 631-634.

Sweetnam, W. P., Murphy, E. F., and Woodcock, R. C. (1952). Acute idiopathic paroxysmal cold haemoglobinuria of non- $c$ syphilitic type in a child. Brit. Med. J., 1, 465-466.

Troxel, D. B., Innella, F., and Cohen, R. J. (1966). Infectious mononucleosis complicated by hemolytic anemia due to anti-i. Amer. J. clin. Path., 46, 625-631.

Wintrobe, M. M. (1946). Clinical haematology, 2nd Ed. p. 807. Lea and Febiger. Philadelphia.

Worlledge, S. M., and Dacie, J. V. (1969). Haemolytic and other anaemias in infectious mononucleosis. In Infectious Mononucleosis, edited by R. L. Carter and H. G. Penman, pp. 8298. Blackwell, Oxford and Edinburgh.

Zarafonetis, C. J. D., and Kent, J. F. (1954). Serologic tests for syphilis in infectious mononucleosis. J. Lab. clin. Med., 43, ○ 253-258. 